\begin{abstract}
Manthan Patil
Engineering Student AnnaSaheb Dange College of Engineering

\& Technology, Ashta, India

Rajesh Gawade

Engineering Student AnnaSaheb Dange College of Engineering \& Technology, Ashta,

India

Shubham Potdar

Engineering Student AnnaSaheb Dange College of Engineering \& Technology, Ashta, India

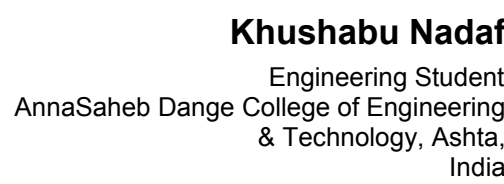

Sanoj P. Suresh

Assistant Professor AnnaSaheb Dange College of Engineering \& Technology, Ashta India

Devabrata Sahoo

\section{Effect of Vortex Generator on the Flow Field over a Conventional Delta Wing in Subsonic Flow Condition at Higher Angles of Attack}

Flow over a conventional delta wing has been studied experimentally at a subsonic flow of $20 \mathrm{~m} / \mathrm{sec}$ and the flow field developed at higher angle of attack varying from $10^{\circ}$ to $20^{\circ}$ has been captured. A vortex generator is mounted on the leeward surface of the delta wing and its effect on the flow field is studied. The set of wing tip vortices generated over the delta wing is captured by the oil flow visualization and the streamline over the delta wing surface captured with and without a vortex generator are compared. Based on the qualitative results, the effect of the vortex generator on the lift coefficient is anticipated. Further, force measurement is carried out to quantitatively analyze the effect of vortex generator on the lift and drag coefficient experienced by the delta wing and justify the anticipation made out of the qualitative oil flow visualization tests. In the present study, the effect of mounting of a vortex generator is found to be minimal on the lift coefficient experienced by the delta wing. However, a significant reduction in the drag coefficient with increase in angle of attack was observed by mounting a typical vortex generator.
\end{abstract}

Assistant Professor MIT School of Engineering MIT ADT University, Pune, 412201 Maharashtra India
Keywords: Subsonic, Lift, Drag, Vortex, Delta Wing.

\section{INTRODUCTION}

With the development of high speed aircraft, the importance of research related to delta wings have increased. Delta wings find usage in supersonic aircraft in order to reduce the wave drag. Although, delta wings are designed for high speed, they still have to take off and land at subsonic speeds. This makes it important to study the flow field over a delta wing and its performance in subsonic flow conditions. In supersonic flight conditions, delta wing reduces wave drag, however in subsonic flight conditions, delta wings are found to be advantageous in terms of lift generation. Delta wings are generally associated with two types of lift: Potential lift and Vortex Lift [1]. Potential lift is the lift generated due to the pressure difference across the surfaces of the delta wing while vortex lift is the additional lift generated due to the formation of wing tip vortices due to the geometry of the delta wing. The schematic of vortices generated over the delta wing moving at subsonic speed at a certain angle of attack shown in Figure 1. At higher angle of attack, the vortices generated at the wing tip of the delta wing results in formation of recirculation region on the leeward face of the delta wing. This recirculation region results in the generation of the vortex lift over the delta wing. As a

Recieved: June 2020, Accepted: January 2021

Correspondence to: Dr Devabrata Sahoo, Aerospace

Engineering Department, MIT School of Engineering, MIT ADT University, Pune, Maharashtra, India-412201

E-mail: devtapu@gmail.com

doi: $10.5937 /$ fme2102395P

(C) Faculty of Mechanical Engineering, Belgrade. All rights reserved result of the generation of vortex lift, delta wing at low speeds and higher angle attack produces additional lift $[2$, 3]. However, there is limitation on the lift due to the existence of stall angle of attack [4]. Wing tip vortices also have their impact on general non-delta wings at subsonic speed as they lead to the generation of induced drag. The induced drag is reduced by the application of winglets and the performance of the wing is improved [5]. Similarly, numerous techniques have been used to improve the performance of delta wing $[6,8]$. Successful enhancement of lift coefficient has been obtained by rounding off of the delta wing edges $[9,10]$. Recent studies report an increase in the stall angle and smoothening of the stalling process by using an appropriate dimension sinusoidal delta wing $[11,13]$. The vortex breakdown phenomena that leads to the stalling of the wing is controlled by various active controls thereby successfully increasing the efficiency of the delta wing [14]. The flow phenomena developing over the delta wing is unsteady in nature and various research studies are carried out focusing on the fluctuating vortex flow and the unsteady vortex breakdown location $[15,16]$. Experimental studies have also been conducted and the aerodynamic parameters have been reported on bodywing configuration representing a generic flying vehicle where the wing shape is in delta formation [17].

As mentioned in the previous paragraph, various passive lift enhancement as well as drag reduction techniques over a delta wing have been already utilised and reported. However, the effect of additional vortex generator on the flow field over the delta wing at high 
angle of attack is yet to be investigated to the best of the authors' knowledge. This research gap on the studies related to delta wings is the prime focus of the present investigation. In the present research, an attempt is made to experimentally study the effect of an additional vortex generator mounted over the wing surface on the flow field over a delta wing. The effect of mounting an additional vortex generator on the delta wing is investigated by conducting qualitative (oil flow visualization) and quantitative (lift and drag measurement) tests at a subsonic freestream flow of $20 \mathrm{~m} / \mathrm{s}$ at different higher angles of attack $\left(10^{\circ}\right.$ to $\left.20^{\circ}\right)$.

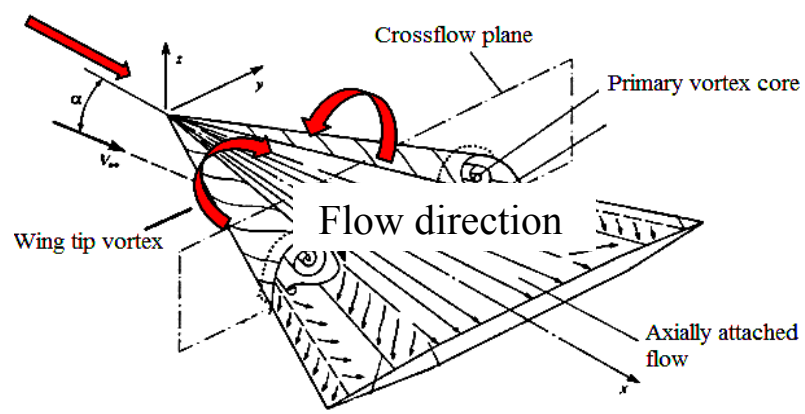

Figure 1. Flow over conventional Delta wing at certain angle of attack in subsonic condition.

\section{TEST MODEL}

A typical delta wing model with geometrical details similar to the delta wing used in [11] has been adopted for the present study. The adopted delta wing model has a critical stalling angle of 26 degree. The model adopted in the present research is made of black acrylic sheet having a thickness of $3 \mathrm{~mm}$. The black colour sheet is used as it will be suitable for oil flow visualization tests (details discussed in the subsequent "experimental methodology" section). In order to study the effect of the vortex generator on the flow field, a typical single wedge type vortex generator is adopted and mounted on the leeward surface of the delta wing. The model photograph of the delta wing and the geometrical details of the delta wing and vortex generator are shown in Figure 2.

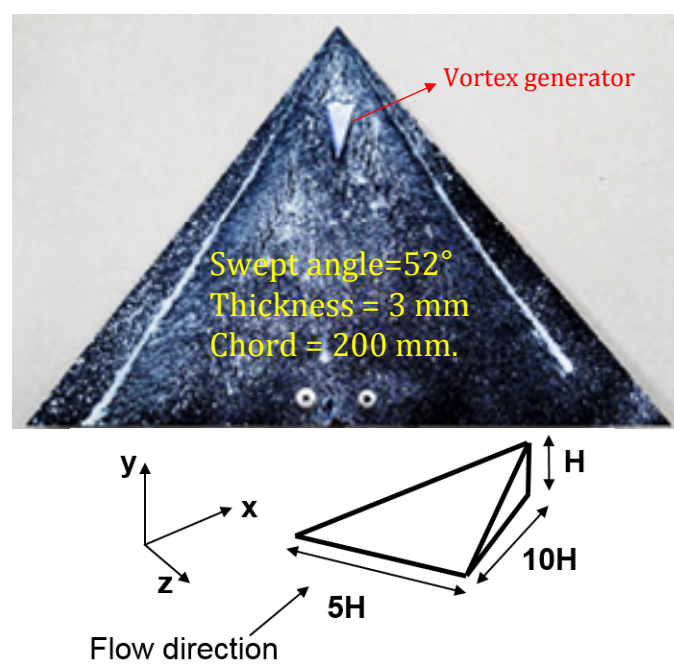

\section{Vortex generator}

Figure 2 Photograph and geometrical detail of the delta wing model and vortex generator adopted in the present investigation. $(\mathrm{H}=0.002 \mathrm{~m})$
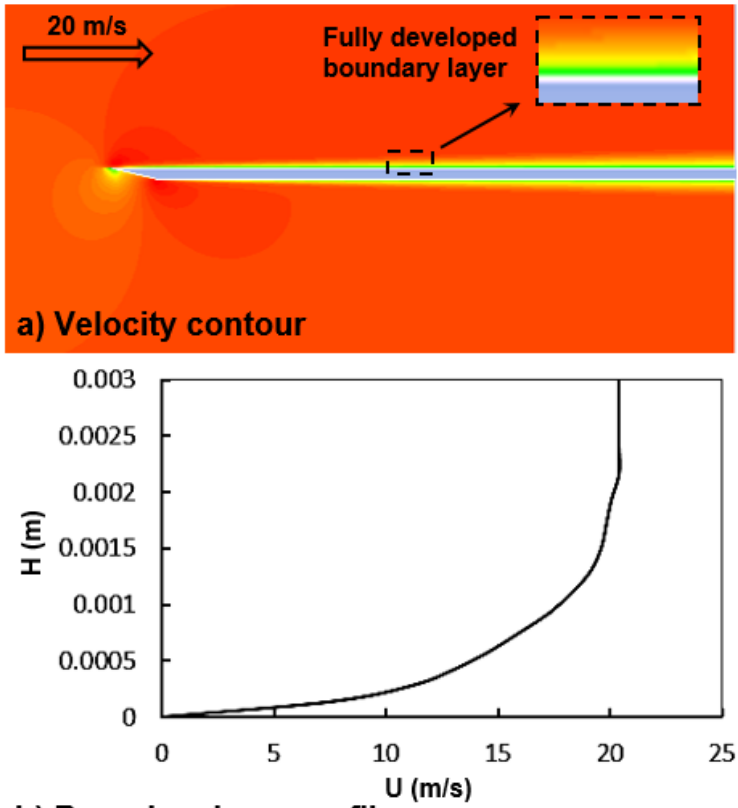

b) Boundary layer profile

Figure 3 Computational result (a. Velocity contour and b. boundary layer profile) obtained over the flat plate in order to obtain the boundary layer height.

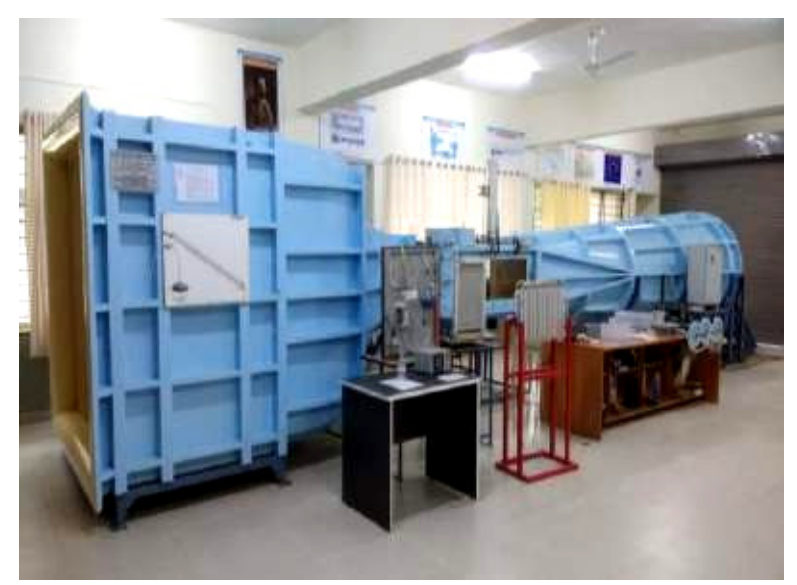

Figure 4. Photograph of the subsonic wind tunnel used in the present investigation.

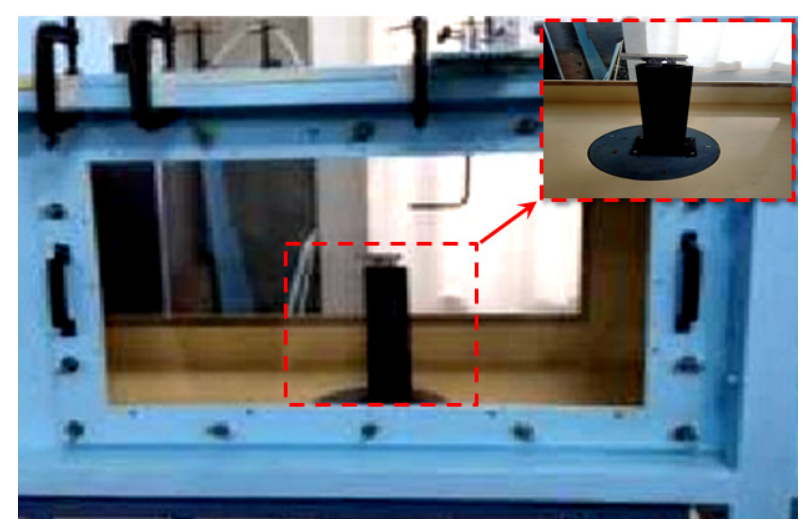

Figure 5. Photograph of the test section of the subsonic wind tunnel along with the model mounting arrangement.

The geometry of the vortex generator utilised in the present research has been adopted from [12]. The height of the vortex generator is kept equal to the height of the fully developed boundary layer over the delta wing at the freestream velocity of the test condition $(20 \mathrm{~m} / \mathrm{s})$. The boundary layer height is obtained by conducting 
Computational Fluid Dynamics (CFD) simulation over a flat plate keeping the same flow conditions as adopted in the present research. The commercial CFD software ANSYS-FLUENT is used for conducting the simulation over the flat plate. The pressure based coupled solver is utilized adopting k- $\omega$ standard turbulence model. The location at which the boundary layer gets fully developed in the flat plate is considered as the location of mounting the vortex generator over the delta wing. The computed flow field captured over the flat plate showing the fully developed boundary layer and the computed boundary layer profile showing the height of the boundary layer is presented in Figure 3. From the boundary layer profile is can be observed that the boundary layer height is around $0.002 \mathrm{~m}$. Hence the height of the vortex generator $(\mathrm{H})$ adopted in the present investigation is also kept to be of $0.002 \mathrm{~m}$. In the present study only one vortex generator has been used and parametric study of the vortex generator is not in the scope of the present research.

\section{EXPERIMENTAL METHODOLOGY}

The wind tunnel present in the aerodynamics lab of AnnaSaheb Dange college of Engineering and Technology, Ashta is utilized to perform the experiments. It is an open loop suction type subsonic wind tunnel having a test section cross section size of $60 \times 60 \mathrm{~cm}$ and a length of $200 \mathrm{~cm}$. The photograph of the subsonic wind tunnel and the close view of the test section with a complete model mounting arrangement is shown in Figure 4 and Figure 5, respectively. The maximum airspeed that can be generated by the subsonic wind tunnel at the test section is $50 \mathrm{~m} / \mathrm{s}$. In the present investigation, all the experiments are carried out at a free stream air velocity of $20 \mathrm{~m} / \mathrm{s}$. For quantitative analysis, the streamlines of the flow generated on the surface of the delta wing are captured using oil flow visualization. For the purpose of oil flow visualization, the black perplex glass sheet is used to fabricate the delta wing models. A mixture of Titanium dioxide and Oleic acid is made to spray over the model surface and generate the stream lines developed during the flow. Titanium dioxide is used because of its high cohesiveness property that will restrict the formation lumps in the mixture sprayed on the model surface. This will result in a formation of proper streamlines. Titanium dioxide is mixed with Oleic acid because of its high refractive index which will allow to have a better contrast on the streamline generated over the surface of the test model. Furthermore, for quantitative analysis the lift and drag coefficients generated by the delta wing with and without vortex generator are measured using a base mounted three component strain gage balance. The balance is powered by a DC voltage of $12 \mathrm{~V}$ and has a capacity of measuring axial and normal forces of $98 \mathrm{~N}$ each. The output is acquired using a PC based Data Acquisition System. Before performing the set of experiments in the present research, the subsonic wind tunnel as well as the strain gage balance have been suitably calibrated. The uncertainty of the drag and lift coefficients measured is found to be less than $\pm 5 \%$.

\section{RESULTS AND DISCUSSION}

The subsonic flow over a simple conventional delta wing has been experimentally investigated. The tip vortices originating from the delta wing frontal tip are captured successfully using oil flow visualization. The variation in the size of the tip vortices with the increase in angle of attack has been clearly captured. Figure 6 shows the flow streamlines captured over the delta wing at an angle of attack of 15 degrees. The tip vortices can be marked and the gradual development of the vortices from the tip of the delta wing can be seen in Figure 6 . As we move towards the downstream of the delta wing the increase in the size of the vortices can also be observed. The boundary of the tip vortices are marked in yellow dashed line for reference in Figure 6. These tip vortices create a suction effect on the upper wing surface (leeward side) and result in generation of an additional lift termed as vortex lift. The amount of the vortex lift generated by the delta wing depends on the strength of the tip vortices. Further, the change in the size of the tip vortices with increase in angle of attack from $10^{\circ}$ to $20^{\circ}$ has been captured and shown in Figure 7. It can be clearly seen that with increasing angle of attack, the size of the tip vortices and hence the strength of the vortices increases. This should result in an increase in the total lift coefficient generated by the delta wing at higher angle of attack.

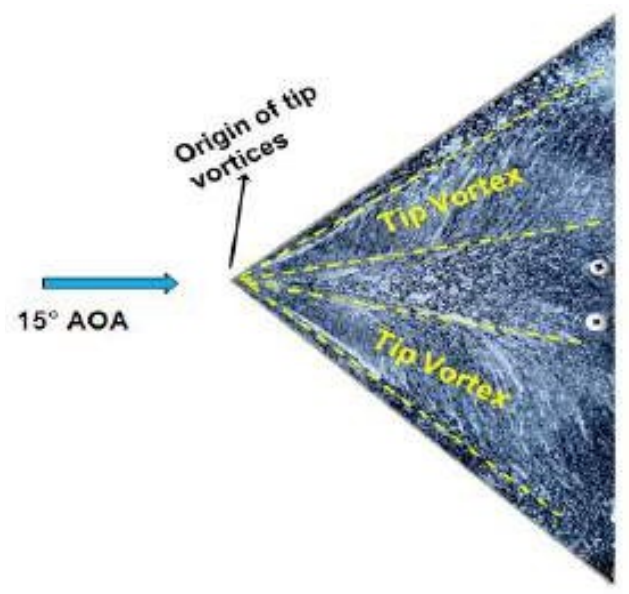

Figure 6 Surface flow captured over the Delta wing configuration at an angle of attack of $15^{\circ}$. Flow is from left to right with a free stream velocity of $20 \mathrm{~m} / \mathrm{s}$.

Later, a vortex generator has been mounted at the flow separation location (found to be around $3.5 \mathrm{~cm}$ from the tip) on the leeward surface of the delta wing and the change in the flow field is studied. The flow streamlines over the delta wing with vortex generator are captured at different angle of attack $\left(10^{\circ}\right.$ to $\left.20^{\circ}\right)$ using oil flow visualization and compared with those captured over the delta wing without any vortex generator. The captured streamlines are shown in Figure 7. It can be clearly seen that in both cases (with and without vortex generator), the size or strength of the tip vortices increases with increase in angle of attack. However, on comparing the streamlines side by side (see Figure 8) to study the effect of vortex generator on the vortex strength, minimal variation was observed. From Figure 8 it can be seen that the 
size of the tip vortex is almost same for all the angle of attack tested in the present study regardless of mounting of a vortex generator. As a result it can be anticipated that the lift coefficient generated by the delta wing should remain similar with addition of single vortex generator on the leeward side of the delta wing.
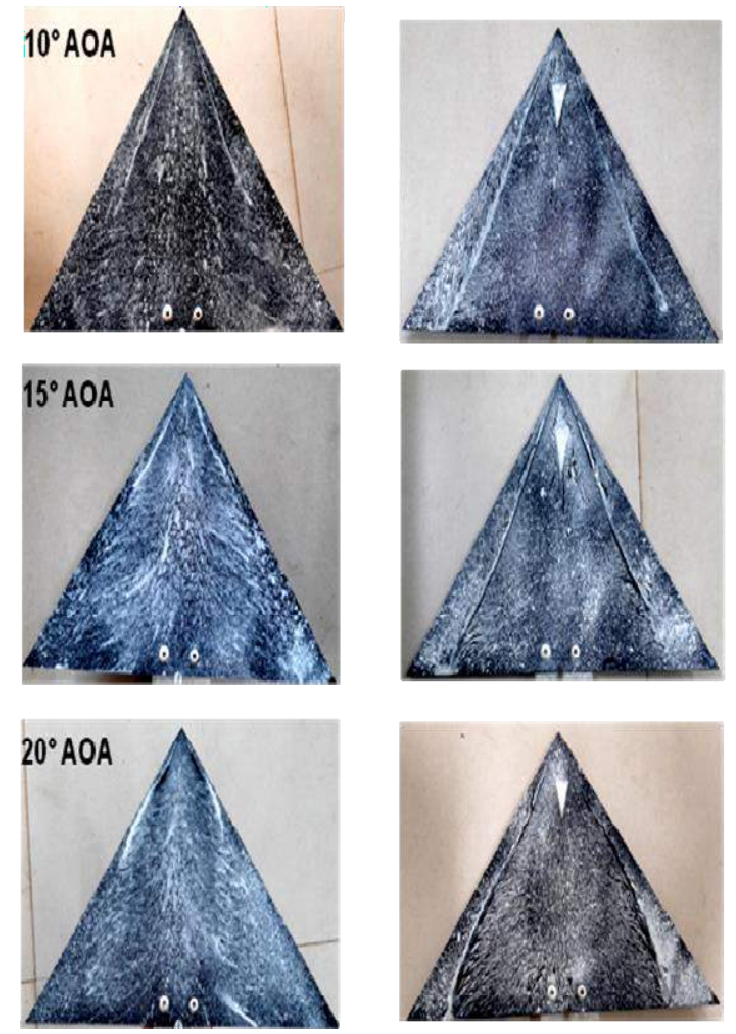

Figure 7 Result of oil flow visualization without and with vortex generator. Flow is from top to bottom with freestream velocity of $20 \mathrm{~m} / \mathrm{s}$. The first coloumn shows the delta wing without an vortex generator and the second coloumn shows delta wing with a vortex generator mmounted.

\section{Without VG With VG}
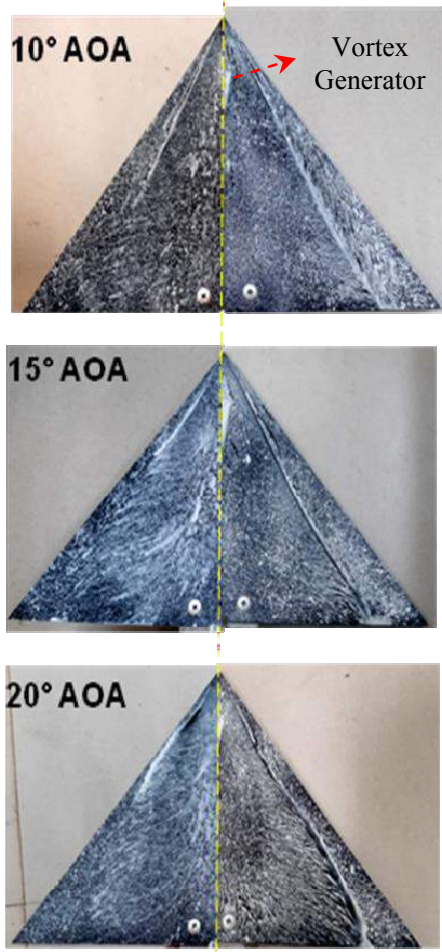

Figure 8 Comparision of the flow streamlines over the delta wing (with and without vortex generator. Flow is from top to bottom with a freestream velocity of $20 \mathrm{~m} / \mathrm{s}$. The left half of each figure shows the delta wing without an vortex generator and the right half of each figure shows the delta wing with a vortex generator mmounted.

Table 1 Drag and Lift Coefficient measured at different angle of attack values over a delta wing with and without vortex generator at a free stream velocity of $20 \mathrm{~m} / \mathrm{s}$.

\begin{tabular}{|c|c|c|c|c|}
\hline \multirow[b]{2}{*}{ Angle of attack (degrees) } & \multicolumn{2}{|c|}{ Drag Coefficient (Cd) } & \multicolumn{2}{|c|}{ Lift Coefficient (Cl) } \\
\hline & Without vortex generator & With vortex generator & $\begin{array}{c}\text { Without vortex } \\
\text { generator }\end{array}$ & $\begin{array}{c}\text { With vortex } \\
\text { generator }\end{array}$ \\
\hline 10 & 0.3126 & 0.2782 & 0.8369 & 0.8522 \\
\hline 12 & 0.4048 & 0.3491 & 0.9156 & 0.9184 \\
\hline 14 & 0.4761 & 0.4516 & 0.9873 & 1.0111 \\
\hline 16 & 0.5460 & 0.4971 & 1.0524 & 1.0423 \\
\hline 18 & 0.6770 & 0.6120 & 1.1785 & 1.1638 \\
\hline 20 & 0.7377 & 0.6688 & 1.2057 & 1.2230 \\
\hline
\end{tabular}
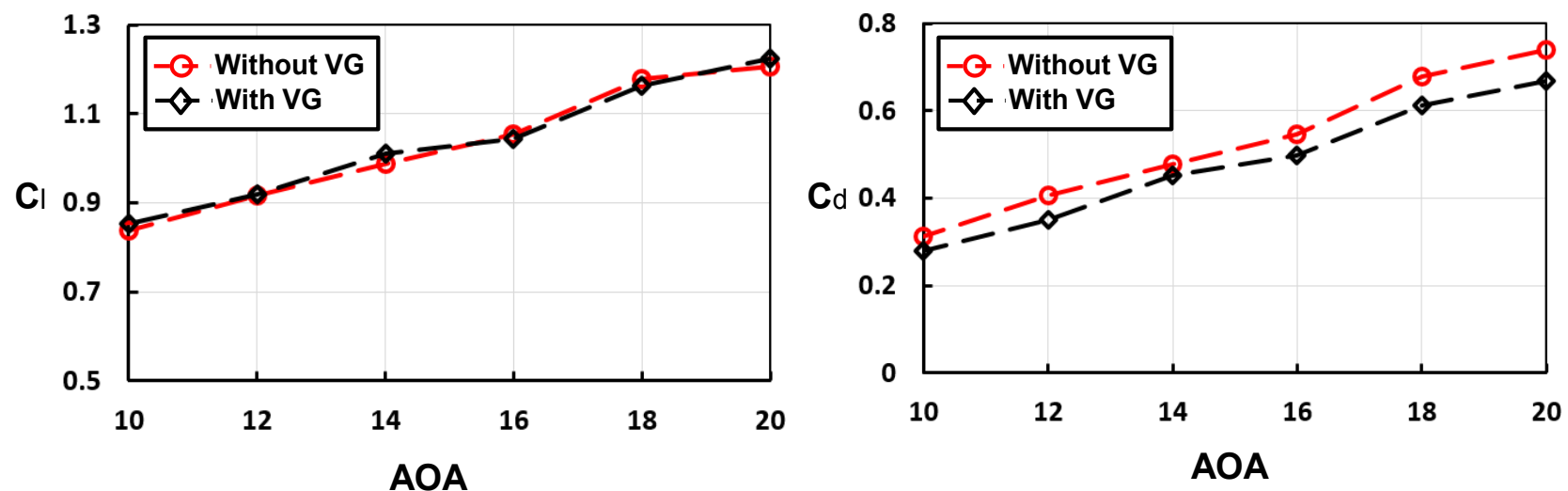

Figure 9 Effect of vortex generator (VG) on lift and drag coefficient experienced by the delta wing at different angle of attack (from 10 to 20 degrees). 
Further, in order to confirm our anticipation from the qualitative (oil flow visualization) analysis through quantitative studies, the lift and drag coefficient have been measured by using a base mounted link based on 3 -component strain gage balance. The coefficient values are measured at different angles of attack $\left(10^{\circ}\right.$ to $20^{\circ}$ with an increment of $2^{\circ}$ ) for the cases of delta wing with and without mounting the vortex generator. The reason behind testing the drag and lift coefficient measurements at higher angle of attack is due to the test model design and experimental limitation as the vibration of the model at zero angle of attack might give doubtful results at zero angle of attack. As the importance of the study of delta wings is generally at higher angle of attack, the present manuscript is focused on study of the flow field at higher angle of attack (10 to 20 degrees). The lift and drag coefficient values measured for both delta wing models (with and without vortex generator) are tabulated in Table 1. The variation in lift and drag coefficient with increasing angle of attack are plotted in Figure 9. Simultaneously, in order to investigate the effect of vortex generator on the flow field over the delta wing at different angle of attack, the variation of the lift and drag coefficient with addition of vortex generator is also plotted in Figure 9. As expected from the qualitative studies, the lift coefficient is observed to have minimal variation on adoption of a vortex generator. However, a significant reduction in the drag values with increasing angle of attack is observed on mounting of the vortex generator. The additional vortices generated by the vortex generator may not be affecting the strength of the already developed tip vortices but they might be affecting the separation angle of the tip vortices. The reduction in drag is only possible if the size of the wake behind the delta wing reduces which is possible if the flow separation angle or the tip vortex angle is reduced. The additional vortices formed by the vortex generator might be dragging the already developed tip vortices towards themselves (which is towards the wing surface). If it is the case then this phenomena will reduce the tip vortex angle (or the flow separation angle) thereby a reduction in the size of the wake will be observed. This will finally result in a reduction in the drag value experienced by the delta wing at different angle of attack. A deeper insight to this phenomena can be obtained by conducting smoke flow visualization tests and also capturing the flow field over the cross flow plane at different axial location along the delta wing surface. This can be included in the scope of future work.

\section{CONCLUSION}

Experiments have been carried out over a delta wing and the effect of mounting a vortex generator on the leeward side of the delta wing over the flow field is analysed. The vortex generator is found to have a minimal effect on the lift coefficient at all tested angles of attack. However, on mounting a vortex generator the drag coefficient values are found to be reduced at all the tested angle of attack. The qualitative results obtained from oil flow visualizations are well justified by the quantitative results obtained by measuring the lift coefficient values.
However, the effect of vortex generator on drag coefficient experienced at different angle of attack could not be completely justified from the qualitative analysis (oil flow visualization) conducted in the present study. The reason behind the reduction in the drag coefficient values by adopting a vortex generator has been proposed in the present paper. However, further in depth study is needed using other flow visualization techniques (smoke flow) to justify the phenomena responsible for the reduction in drag. In addition, the effect of location of the vortex generator on the flow field over the delta wing can also be included in the scope of future research.

\section{REFERENCES}

[1] Polhamus, E. C.: A Concept of the Vortex Lift of Sharp-Edge Delta Wing Based on a Leading Edge Suction Analogy, NASA Technical Note, TN-D3767, Dec. 1966.

[2] Devenport, W. J., Rife, M. C., Liapis, S. I., and Follin, G. J.: Structure and Development of a Wing Tip Vortex, Journal of Fluid Mechanics, Vol. 312, 1996, pp. 67-106.

[3] Hummel, D. J.: The international vortex flow experiment 2 (VFE-2): background, objectives and organization, Aerospace Science and Technology, vol. 24, no. 1, pp. 1-9, 2013.

[4] Lee, M., and Ho, C. M.: Lift Force of Delta Wings, Applied Mech. Rev, Vol. 43, Sept. 1990, pp. 209-221.

[5] Nikola N. Gavrilović, Boško P. Rašuo, George S. Dulikravich, Vladimir B. Parezanović,: Commercial Aircraft Performance Improvement Using Winglets, FME Transactions, Vol.43, pp.1-8, 2015.

[6] Gurusul, I.: Recent Developments in Delta Wing Aerodynamics, The Aeronautical Journal, Sept. 2004, pp. 437-452.

[7] J. Chu and J. M. Luckring: Experimental surface pressure data obtained on $65^{\circ}$ delta wing across Reynolds number and Mach number ranges, NASA Technical Memorandum 4645, 1996.

[8] Chen L, Wang J J, Zuo L X, et al.: Influence of Reynolds number on vortex flow over a nonslender delta wing, AIAA J, 2010, 48: 2831-2839

[9] W. Fritz: Numerical simulation of the peculiar subsonic flowfield about the VFE-2 delta wing with rounded leading edge, Aerospace Science and Technology, vol. 24, no. 1, pp. 45-55, 2013.

[10] S. Mat,: The Analysis of Flow on Round-Edged Delta Wings [Ph.D. dissertation], University of Glasgow, Glasgow, UK, April 2010.

[11] Pan, C. and Wang, J.: Effects of Sinusoidal Leading Edge on Delta Wing Performance and Mechanism, Science China Technological Sciences, Vol. 56 (3), March 2013, pp. 772-779.

[12] Chen, H. and Wang J.: Vortex Structures for Flow over a Delta Wing with Sinusoidal Leading Edge, Exp. Fluid, Vol. 55, 2014.

[13] Goruney T, Rockwell D.: Flow past a delta wing with a sinusoidal leading edge: near-surface 
topology and flow structure, Exp Fluids, 2009, 57: 321-331.

[14] Gursul, I., and G. Batta.: Active control of vortex breakdown over a delta wing, AIAA Journal Vol. 33, No. 9, 1995, pp.1743-1745.

[15] Gursul, I.: Review of unsteady vortex flows over slender delta wings, AIAA Paper 2003-3942.

[16] Gursul, I., and Houbin Yang.: On fluctuations of vortex breakdown location, Physics of Fluids, Vol. 7, No. 1, 1995, pp. 229-231.

[17] Goran Ocokoljić, Dijana Damljanović, Đorđe Vuković, Boško Rašuo: Contemporary Frame of Measurement and Assessment of Wind-Tunnel Flow Quality in a Low-Speed Facility. FME Transactions, Vol. 46, No. 4, pp. 429-442, 2018.

УТИЦАЈ ГЕНЕРАТОРА ВРТЛОГА НА СТРУЈНО ПОЉЕ ОКО КОНВЕНЦИНАЛНОГ

ДЕЛТА КРИЛА У УСЛОВИМА ПОДЗВУЧНОГ СТРУЈАЊА ПРИ ВЕЋИМ НАПАДНИМ УГЛОВИМА

\section{М. Патил, Р. Гаваде, Ш. Потдар, К. Надаф, С.П. Суреш, Д. Саху}

Рад приказује експериментално истраживање струјног поља по површини конвенционалног делта крила при подзвучном струјању од 20 м/сец и при већим нападним угловима од $10^{\circ}-20^{\circ}$. Генератор вртлога је постављен на заветринској страни делта крила и истражен је његов утицај на струјно поље. Генерисани вртлози визуализирају се струјним током уља по површини делта крила и врши се поређење вртлога са и без генератора вртлога. На основу квалитативних резултата предвиђа се утицај генератора вртлога на коефицијент силе узгона. Мерења силе се врше у циљу квалитативне анализе утицаја генератора вртлога на коефицијенте силе узгона и силе чеоног отпора код делта крила и предвиђања квалитативног испитивања визуализацијом токова уља. Утврђено је да постављени генератора вртлога има минимални утицај на коефицијент силе узгона. Међутим, вртложник има утицаја и на значајно опадање вредности коефицијента чеоног отпора при повећању нападног угла. 